\title{
GRACCHO CARDOSO, ABDIAS BEZERRA, JOSÉ DE ALENCAR CARDOSO E O MOVIMENTO RENOVADOR NA EDUCAÇÃO ESCOLAR SERGIPANA NA DÉCADA DE 1920
}

\author{
Crislane B. Azevedo ${ }^{1}$ \\ Universidade Federal do Rio Grande do Norte
}

\section{RESUMO}

Neste texto apresentamos resultados de pesquisa sobre a educação em Sergipe no início do século XX, com foco nas representações acerca da educação presentes em intelectuais sergipanos na década de 1920 e o papel desempenhado por estes frente à instrução pública do estado. Entre tais agentes destacam-se Graccho Cardoso, Abdias Bezerra e José de Alencar Cardoso. Em termos metodológicos trabalhamos com pesquisa bibliográfica e documental. Com base na perspectiva da história cultural a partir dos conceitos de apropriação e representação definidos por Chartier (1990) tornou-se possível a compreensão dos processos educacionais do período. Durante o governo de Graccho Cardoso em Sergipe (1922-26), estiveram no comando da Diretoria da Instrução os professores Abdias Bezerra e José de Alencar Cardoso, ambos, dotados de uma sólida formação científica. Tais jovens intelectuais sergipanos representavam, no governo Graccho, apoio para a efetivação de um projeto político de modernização do estado por meio da educação.

Palavras-chave: Intelectuais da educação; Sergipe; Grupos escolares.

\section{GRACCHO CARDOSO, ABDIAS BEZERRA, JOSÉ DE ALENCAR CARDOSO AND RENEWAL MOVEMENT IN SCHOOLING SERGIPANA IN THE DECADE 1920}

\begin{abstract}
In this study we investigated the representations of education present in Sergipe intellectuals in the 1920s and the role played by these front of public education in the state. Among such agents stand out Graccho Cardoso, Abdias Bezerra Cardoso and José de Alencar. The methodological work with literature and documents. From the perspective of cultural history from the concepts of ownership and representation in a manner established by Chartier (1990) it became possible to understand the educational processes of the period. During the Cardoso government Graccho Sergipe (1922-26), were in charge of the Directorate of Education teachers Abdias Bezerra Cardoso and José de Alencar, both endowed with a solid scientific background. These young intellectuals sergipanos represented in government Graccho, support for the realization of a political project of modernization of the state through education.
\end{abstract}

Keywords: Intellectual education - Sergipe - School groups.

O contato com estudos sobre a história da educação em Sergipe, sobretudo, em relação aos grupos escolares, revelou-nos um movimento educacional modernizador durante a administração Graccho Cardoso (1922-1926). O estado de Sergipe assistiu à expansão dos grupos escolares nos anos de 1923 a 1925. Na investigação de outros indícios acerca da referida expansão, deu-se o contato com iniciativas educacionais propostas para outros níveis de escolarização e a implementação de uma reforma da 
instrução pública em 1924. Nesse cenário, destacamos o trabalho dos diretores da instrução pública, Abdias Bezerra e José de Alencar Cardoso.

Diante de questionamentos sobre a implantação dos grupos escolares em Sergipe bem como do significado e do alcance de reformas educacionais no estado, nesta pesquisa investigamos as representações acerca da educação presentes em intelectuais sergipanos na década de 1920 e o papel desempenhado por estes frente à instrução pública. Entre tais agentes destacamos Graccho Cardoso, Abdias Bezerra e José de Alencar Cardoso. Em termos metodológicos trabalhamos com pesquisa bibliográfica e documental. Entre os documentos de época analisados, destacamos: relatórios do diretor geral da instrução, inspetores escolares e diretores de grupos escolares; Mensagens presidenciais e discursos de Graccho Cardoso; regulamentos e programas de ensino; documentos manuscritos relativos ao ensino primário; artigos de jornal e legislação. A pesquisa historiográfica voltou-se para a educação brasileira. Com base na perspectiva da história cultural a partir dos conceitos de apropriação e representação nos moldes definidos por Chartier (1990) tornou-se possível a compreensão dos processos educacionais do período.

De acordo Chartier, a noção de apropriação pode ser colocada no centro de uma abordagem de história cultural que se prende a práticas diferenciadas, uma vez que as ações por meio das quais um leitor, por exemplo, apropria-se de um texto são histórica e socialmente variáveis (1990, p.24-25). Assim, apropriação consiste em ações que geram, em consequência, novas práticas. As condições e os processos passam a ser considerados determinantes das operações de construção do sentido. Apropriação pode ser considerada um processo de interpretação de vivências e realidades - próprio de cada indivíduo e decorrente das concepções prévias deste sobre tais vivências e realidades. Isto é, as experiências, os interesses, os conhecimentos de cada indivíduo implicam na forma como este assimila as novas concepções e experiências com as quais se depara, levando-o à construção de novas representações e práticas (1990, p.26-27). Uma investigação relativa a ações de intelectuais do início do século $\mathrm{XX}$, preocupada com processos de apropriação nos termos em que se refere o autor, tem como fim uma análise das interpretações e das ações dos sujeitos levando-se em consideração aspectos sociais, institucionais e culturais.

$\mathrm{Na}$ história da educação no Brasil é possível encontrarmos uma produção acadêmica cujo tema relaciona-se a intelectuais. Vieira (2008) destaca as mudanças de orientação teórica nesse corpo de investigações, enfatizando concepções de diferentes autores, tais como Dilthey, Gramsci e Bourdieu no decorrer da segunda metade do século XX. Contudo, Sirinelli (2003) salienta que ainda em meados da década de 1960, os estudos desenvolvidos sob a perspectiva histórica eram tímidos quantitativamente. $\mathrm{O}$ aumento dessa produção teria ocorrido em meio ao renascimento da história política, a partir da qual os intelectuais puderam ser analisados como atores políticos e suas ações passavam a ser analisadas levando-se em consideração práticas políticas, sociais e culturais. Logo, pesquisar sobre intelectuais requer do investigador desprendimento para lidar com um campo aberto de possibilidades as quais se encontram no entrecruzamento da história política, social e cultural.

Os intelectuais alvos desta pesquisa foram analisados tendo como foco as suas ações na esfera educacional. Pesquisas com esse propósito têm aumentado no Brasil, o que pode ser verificado pela quantidade de teses e dissertações sobre intelectuais da educação no País. O próprio Ministério da Educação, ao publicar a Coleção de Educadores em seu portal na internet põe em público livros sobre diferentes intelectuais com atuação na educação, tais como Anísio Teixeira, Fernando de Azevedo e Roquette Pinto.

Acerca do que vem a ser intelectual, nesta pesquisa trabalhamos com o sentido de noção, assim, não considerando a definição de intelectual como portadora de contornos 
fechados. Como declara Gomes (1999), trabalhar a categoria "intelectual" como noção significa ter a percepção de algo fluído e que se transforma com o tempo. Nesse sentido, não existiria uma definição a priori do que deveria existir em termos de formação e vinculação institucional para que determinado sujeito pudesse ser considerado intelectual. Contudo, há um aspecto a ser considerado: as relações públicas e privadas inerentes a um determinado grupo de intelectuais inseridos em uma geração. De acordo com Gomes (1999) a noção de geração implica em um trabalho de memória de um grupo que compartilha experiências e as transmite aos seus sucessores. Assim, buscamos analisar as relações existentes entre Graccho Cardoso, Abdias Bezerra e José de Alencar Cardoso e destes com os aspectos educacionais no Sergipe republicano.

A preocupação com a educação caracterizou a trajetória política de Graccho Cardoso até o seu governo à frente do Executivo estadual em Sergipe entre 1922 e 1926. Nascido na cidade de Estância-SE em 1874 em uma família já caracterizada pela presença em atividades intelectuais, teve seu pai como o primeiro mestre, Brício Cardoso, o qual se tornou um conceituado professor do Atheneu Sergipense. Seu avô, Joaquim Maurício Cardoso, foi, além de advogado, professor de Matemática e Geografia. Seu tio, Severiano Cardoso, era professor e escritor. Os primeiros estudos de Graccho Cardoso tiveram prosseguimento em Aracaju, depois no Rio de Janeiro, onde estudou na Escola da Praia Vermelha. Finalmente ingressou na Escola Militar do Ceará, estado onde depois, em 1907, concluiu o curso de Direito. No Ceará atuou também como jornalista. A experiência como proprietário e redator de "O Republicano" contribuiu para o seu envolvimento com a vida política. Naquele estado trabalhou com os Accioly, ocupando vários cargos públicos: diretor da Secretaria da Assembleia Legislativa Estadual, professor concursado do Lyceu do Ceará, lente de Direito Constitucional da Faculdade de Direito, deputado estadual por duas legislaturas, secretário da Fazenda no $2^{\circ}$ Governo Accioly e deputado federal, momento em que foi eleito também vice-presidente do Ceará entre 1908 e 1912 (GUARANÁ, 1925). Após a queda dos Accioly, afastou-se dos cargos públicos administrativos, retornando a eles posteriormente, mas em Sergipe.

Como deputado federal, na primeira década do século $\mathrm{XX}$, a atenção à educação em todos os níveis fazia parte dos discursos de Graccho. Em relação ao ensino primário, a defesa da obrigatoriedade era a máxima. Ao lado disso figurava a defesa da educação popular como base para a República e a Democracia. Esta educação fazia parte das suas proposições igualmente como elemento mantenedor da ordem e da prosperidade da pátria, premissas visíveis, também, na sua posterior administração como presidente do estado de Sergipe. A instrução pública aparecia frequentemente nas falas do administrador. Em sua plataforma presidencial, ao se referir à instrução pública, atestava o muito já feito em Sergipe, mas, ao mesmo tempo, salientava a insuficiência das ações. Afirmava que "no terreno da instrucção publica, notadamente da primaria, pode o nosso ousado e pequeno Sergipe orgulhar-se de haver realisado obra palpitante e notável de todas a que mais de perto entende com os altos problemas da vida e o progresso moral e econômico do Estado" (CARDOSO. Diario Official..., 27/10/1922, p.17).

Atento às necessidades de reorganização da formação docente para atender a novos programas de ensino primário, o governante afirmava que o ensino normal deveria "estabelecer um justo equilibrio entre as sciencias e as letras, e bem assim o criterio da experimentação nas diversas classes de matérias" (CARDOSO. Diario Official..., 27/10/1922, p.18). Além disso, detinha-se na defesa da educação profissional, que segundo ele, deveria ser trabalhada como complemento mesmo do ensino primário "de maneira que o alumno da escola primaria tenha ao seu alcance os meios de adquirir os conhecimentos 
práticos que lhe permittam o exercicio de uma profissão neste ou naquelle ramo da industria nacional" (CARDOSO. Diario Official..., 27/10/1922, p.23).

Os discursos e propostas de ação do governante demonstravam a defesa da instrução pública como uma das tarefas mais importantes a ser desenvolvida pelo Governo e a necessidade de estudos e adoção de métodos racionais em prol do desenvolvimento econômico. Portanto, revelavam seu defensor como um homem que acreditava no progresso, esperança que influenciou sua administração na década de 1920.

No campo econômico, o cuidado com o desenvolvimento do estado gerou investimento na imigração alemã, na criação do Banco do Estado de Sergipe e na fundação de instituições voltadas para pesquisa sobre produção agrícola. Foram exemplos o Instituto de Química Industrial e o Laboratório Químico de Análises, no Centro Agrícola Epitácio Pessoa, órgão oficial de estudos agrícolas de Sergipe, reorganizado a partir de 1922. Consciente da limitação das inovações técnicas e científicas diante da falta de instrução daqueles que mais diretamente trabalhavam com a agricultura, o governo Graccho construiu o Patronato São Maurício inaugurado em 1924, no Centro Agrícola.

[...] O Patronato São Mauricio, no Centro Agricola Epitacio Pessoa, constituirá a primeira escola destinada ao preparo de jornaleiros, para as diversas lavouras do Estado. Atraz do ensino agricola primário simples, virão, ad instar das estações de algodão, os campos de demonstração, intuitivos, economicos e modestos, e da diffusão delles resultará a victoria da cultura racional sobre os meios broncos que, por séculos, vêm immobilizando a fortuna e a grandeza do Brasil. (SERGIPE. Mensagem..., 1923, p. 37-38).

O administrador acreditava na agricultura como fator de desenvolvimento do Brasil, desde que fossem adotados métodos científicos, a pequena propriedade e um sistema de créditos para os agricultores assim como um ensino agrícola (CARDOSO. Diario Official..., 05 a 08/03/1922). Os agricultores sergipanos eram apresentados por Graccho Cardoso como ainda muito tradicionais quanto ao emprego de técnicas agrícolas. Nesse aspecto apontava a necessidade da adoção de modernos processos mecânicos para a produção.

Os cuidados para com a agricultura ocorriam também no âmbito da indústria, principalmente à têxtil. Graccho Cardoso registrava em 1926 um aumento no movimento industrial de Sergipe. As nove fábricas de tecidos juntas eram responsáveis pelo consumo de $80 \%$ da produção da safra de algodão 1924-25 e 90\% da safra 1925-26 (SERGIPE. Mensagem..., 1926, p. 52-53).

Em relação à criação e expansão de instituições e serviços, foi grande a diversificação, atendendo à quase totalidade do que preceituava a sua plataforma de governo. Por meio de uma política de mudanças a serem materializadas pelo governo estadual, o presidente demonstrava a sua crença na implantação do moderno através da sua administração. Essa modernização materializar-se-ia por meio de reformas. A base orientadora das mudanças era a ciência, a racionalização e o controle dos processos por especialistas, numa demonstração da influência de ideias positivistas, tão presentes entre os intelectuais e administradores públicos do período (CRUZ COSTA, 1967).

As reformas abarcavam mudanças em órgãos públicos e serviços existentes, bem como a criação de novas instituições consideradas modelo, a exemplo do mercado e do matadouro públicos e da penitenciária do estado, localizados na capital. Graccho Cardoso, na gerência do Poder Executivo sergipano, defendia um Governo fiscalizador da sociedade 
e promotor do desenvolvimento. Para tanto, entre outros aspectos, advogava em favor de estudos científicos e da fundação de institutos de pesquisa e do financiamento destes, premissa materializada na construção e no funcionamento de instituições como: o Hospital de Cirurgia, o Instituto Parreiras Horta, o Instituto de Química e as Faculdades de Direito, Farmácia e Odontologia.

A Faculdade de Direito Tobias Barreto foi alvo de censuras transmitidas pela imprensa local. Mesmo diante de críticas o Governo Graccho Cardoso insistia na sua proposição de implantação do ensino superior em Sergipe. Assim, criou também a Faculdade de Farmácia e Odontologia que iniciou o seu funcionamento em abril de 1926. Levantava-se o Sergipe Jornal, em 07 de abril de 1926, e criticava a iniciativa: "Uma Escola de Direito, uma dita de Farmácia e Odontologia, uma outra de Comércio, enquanto o povo se torce absorvido pela carestia pavorosa da vida". Em relação à Faculdade de Direito, apesar de inaugurada em 1924, até o ano seguinte não havia entrado em funcionamento devido à falta de matriculados. Francisco Nobre de Lacerda, diretor interino da instituição, atribuiu tal fracasso ao fato de não ser a Faculdade de Direito Tobias Barreto equiparada aos demais estabelecimentos oficiais congêneres (SERGIPE. Mensagem..., 1926).

O Instituto de Química foi fundado em 27 de junho de 1923 e destinava-se a análises e pesquisas. Segundo Graccho, "nada ficará a dever [...] ao seu congênere de Bello Horisonte e aos cursos das Polytechnicas do Rio de Janeiro, de Porto Alegre, de Curitiba, de S. Paulo, da Bahia, de Ouro Preto e de Pernambuco e da Escola de Agricultura de Nictheroy" (SERGIPE. Mensagem..., 1925, p.36). De acordo com o Presidente, "um instituto ou uma escola de chimica, qualquer dos dois, dá perfeitamente idea do estado de adiantamento da producção em qualquer parte em que se reconheça a absoluta necessidade do controle scientifico sobre o desenvolvimento industrial" (SERGIPE. Mensagem..., 1925, p.37).

Da criação das instituições e serviços aqui exemplificados percebemos preocupação com a mudança; com a ruptura de processos, de rotinas tradicionais para atividades científicas em diferentes aspectos da sociedade, através da preocupação com a mecanização da produção agrícola, fundação de institutos e laboratórios de pesquisa, criação de instituições modelo próprias de uma sociedade urbana, por exemplo, assim como investimentos na contratação de profissionais especializados para a organização e a direção de instituições e serviços ${ }^{2}$ e o estabelecimento do ensino superior, mesmo diante de críticas. Esses feitos revelam um processo modernizador. O insucesso de iniciativas como a Faculdade de Direito não deixam de revelar uma esperança no desenvolvimento local.

Tendo em vista o lugar ocupado pela instrução pública, merece menção dados relativos a todo o quadriênio da administração Graccho. Sobre a receita arrecadada e a despesa efetuada pelo governo estadual no período de outubro de 1922 a junho de 1926, observamos um lugar de destaque para as atividades de instrução entre os demais serviços públicos permanentes. Na Tabela 1 são apresentados dados relativos à instrução pública dentro dos gastos totais de 35.944:668\$706 dos quatro anos de governo (SERGIPE. Mensagem..., 1926).

A partir dos dados da Tabela 1 percebemos que durante o quadriênio Graccho Cardoso, de uma despesa geral de 35.944:668\$706 foi depreendido com instrução pública aproximadamente $11,74 \%$. Esse percentual, no entanto, não deve ser visto de modo exato, visto que não foram contabilizados os gastos com a construção e reformas de prédios escolares, posto que tais custos não foram especificados no Demonstrativo Financeiro do Governo. O Demonstrativo apresenta apenas o registro de gastos no valor de 11.364:881\$390 no item “Obras novas, conservação e melhoramentos nas existentes". Foi 
verificado, no entanto, por exemplo, a existência da construção de nove novos grupos escolares e outros prédios para dois grupos já existentes (General Valladão e General Siqueira), a construção do novo Atheneu, do Instituto de Química, do Patronato São Maurício e do Instituto Profissional Coelho e Campos, além de compra de casas para escolas isoladas. Tal fato pressupõe um percentual maior de utilização do orçamento público para os serviços de instrução.

Tabela 1 - Demonstrativo de despesas efetuadas pelo Estado com Instrução Pública ${ }^{3}$ - outubro de 1922 a junho de 1926 -

\begin{tabular}{l|c}
\multicolumn{1}{c|}{ Despesa efetuada } & Valores \\
\hline Biblioteca Pública & $75: 595 \$ 627$ \\
\hline Diretoria de Higiene & $321: 986 \$ 966$ \\
\hline Instrução Pública & $3.132: 358 \$ 756$ \\
\hline Patronato São Maurício & $42: 508 \$ 385$ \\
\hline Instituto Coelho e Campos & $508: 211 \$ 540$ \\
\hline Instituto de Química & $126: 878 \$ 070$ \\
\hline Aquisição de livros e material escolar para alunos pobres & $3: 858 \$ 340$ \\
\hline Aquisição e reforma de mobiliário escolar & $9: 110 \$ 743$ \\
\hline \multicolumn{2}{c}{ Total $\ldots$} \\
\hline
\end{tabular}

Fonte dos dados: SERGIPE. Mensagem..., 1926, p. 100-101.

O presidente Graccho Cardoso assumiu o governo de Sergipe em outubro de 1922 referindo-se à instrução pública em tom de crítica. Em sua opinião, tal instrução, com a qual a administração pública estadual despendia cerca da sexta parte do que arrecadava, ainda não correspondia aos resultados esperados. Para tanto, entre outros aspectos, ressaltava a pequena quantidade de alunos concluintes no ensino primário:

Dos 10.032 alumnos matriculados nos grupos e escolas isoladas no anno de 1922, apenas 160 terminaram o curso primário de 4 annos, retirandose a maioria no $2^{\circ}, 3^{\circ}$ e $4^{\circ}$ annos, antes dos exames finaes. Desses 160 alumnos que terminaram o curso, 102 são do sexo feminino e apenas 58 do sexo masculino, assim distribuídos: nos grupos escolares da capital, 88, sendo 23 meninos e 65 meninas; no grupo escolar da Capella, 5, sendo 4 meninos e uma menina, e nas escolas isoladas, 67, dos quaes 31 meninos e 36 meninas. (SERGIPE. Mensagem..., 1923, p. 7).

As críticas à distribuição das cadeiras pelo governo eram ainda mais enfáticas. De acordo com o presidente, muitas das escolas estavam destituídas das condições de salubridade e higiene necessárias para o processo de ensino. Ao falar sobre a inspeção escolar, remetia-se à sua precariedade e afirmava que sem inspeção técnica constante e competente o ensino não passaria de arremedo caro e criminoso (SERGIPE. Mensagem..., 1923, p. 6). O intuito de reformar a instrução pública fazia-se presente nas palavras do governante em 1923. Afirmava ele que: 
E' chegado o momento de encarardes o problema cuja solução tantas vezes se há buscado já, sendo-me infinitamente grato contribuir para a sanç̧ão de uma lei de reforma do ensino primario em geral, lei que consulte sobretudo a índole e as tendencias do povo para que for votada. (SERGIPE. Mensagem..., 1923, p. 8).

As denúncias eram, contudo, acompanhadas de ações. Já em novembro de 1922, restaurava o Curso Comercial do Atheneu, acrescido da cadeira de Higiene Geral. Em abril do ano seguinte, criava uma Escola de Comércio, desintegrando do Atheneu o curso criado. A partir de agosto também de 1923 a Escola passava a ser denominada de Escola de Comércio Conselheiro Orlando (SERGIPE. Colleção..., 1929).

Outro conjunto de ações consistiu na transformação de prédios de antigas cadeias em escolas, amparado pelo Decreto n. 783, de 24 de fevereiro de 1923. Os municípios beneficiados foram: Itabaiana, Laranjeiras, Estância, Capela, Vilanova (Neópolis), Lagarto, Santo Amaro das Brotas e São Cristóvão. Efetivamente as cadeias de Lagarto e de São Cristóvão passaram pela transformação e se constituíram em grupos escolares. O ensino primário ministrado em grupos escolares, a partir de 1923, portanto, ganhava novas instituições. A partir de então foram inaugurados: o Grupo Escolar Gumercindo Bessa, em Estância; o Grupo Escolar Sílvio Romero, em Lagarto; o Grupo Escolar Vigário Barroso, em São Cristóvão e o Grupo Escolar Olympio Campos, em Vilanova. Em 1924, foram inaugurados os Grupos Escolares "Manoel Luís", em Aracaju e "João Fernandes de Brito", em Propriá. No ano seguinte, entraram em funcionamento os Grupos "Fausto Cardoso", em Anápolis (Simão Dias); "Severiano Cardoso", em Boquim e "José Augusto Ferraz", em Aracaju.

A inauguração do Grupo Escolar Vigário Barroso foi um instante propício para o presidente defender a necessidade da construção de lugares próprios para a escola. Ao mesmo tempo demonstrava a apropriação de concepções sobre educação presentes em Rui Barbosa (1883). Afirmava o presidente:

Entendo, por conseguinte, que o mais salutar beneficio, o supremo bem que um governo póde fazer a um município ou a uma cidade, é dedicarlhe um estabelecimento de ensino capaz de objectivar as aspirações de um gremio social esforçado e intelligente. A construcção de casas para escolas assume esta dupla importância: hygienica e pedagógica, e, portanto, deve competir á acção continua e systematica do Estado. Edifiquemos casas para escolas em todas as localidades em que estas existirem, e teremos resolvido cincoenta por cento o problema do cultivo do espírito popular. Ruy Barbosa escreveu: "Não há instrucção sem escolas, nem escolas sem casas escolares". Mas, á situação do prédio, convem que se alliem o arejamento perfeito, a distribuição scientifica e orientada da luz, o mobiliario completo e adequado, os exercicios physicos e os jogos recreativos. Pelo que respeita á parte pedagógica, ao lado do papel didactico do livro, é preciso coexistir a intervenção educadora do mestre, actuando pelo influxo invariável do conselho e do exemplo, um e outro modelando e forjando os elementos laboriosos resistentes e fortes da raça. [...]. (CARDOSO. Diario Official..., 04/09/1923, p. 2836-2837).

Nos relatórios oficiais a política educacional esteve sempre presente. Exemplo disso foi a promulgação da Lei n. 852, de 30/10/1923, que estabelecia as bases para a reforma do ensino primário e normal do estado. A Lei estabelecia definições e diretrizes 
essenciais como a defesa dos "jardins de crianças", das "escolas rurais" e das escolas dos povoados, e a exigência de trabalhos manuais e noções de agricultura e pecuária para meninos e trabalhos de agulha e economia doméstica para meninas. A Lei determinava inspeção médico-sanitária nas escolas, e a nomeação, pelo Governo, das docentes das escolas rurais. Em cada escola deveria haver biblioteca. Além disso, a lei abria caminho para a criação das chamadas "escolas maternais", que deveriam funcionar "junto aos estabelecimentos fabris que se prontifiquem a fornecer casa e alimentação".

Durante a administração Graccho Cardoso estiveram no comando da Diretoria Geral da Instrução Pública os professores Abdias Bezerra e José de Alencar Cardoso, ambos, assim como o próprio Presidente do Estado, egressos da Escola Militar da Praia Vermelha, grupo que segundo Calazans Silva, formava uma das matrizes do pensamento cultural sergipano. O historiador Calazans ao analisar o desenvolvimento cultural no estado de Sergipe, toma o Instituto Histórico e Geográfico de Sergipe como ponto de partida, enfatizando dois períodos: o ano de fundação, 1912 e o ano de seu cinquentenário. No início do século XX, segundo o historiador, o Instituto funcionou como principal difusor cultural em Sergipe e nele concentraram-se as diversas matrizes do pensamento sergipano. José Calazans Silva identifica cinco matrizes: os bachareis do Recife; os doutores da Bahia e do sul; os padres de D. José Tomás Gomes da Silva; os poetas de Aracaju e os egressos das Escolas Militares (SILVA, 1965).

Graccho Cardoso, Abdias Bezerra e José de Alencar Cardoso podem ser considerados membros de um grupo, compartilhavam da mesma formação, estavam imbricados em um ambiente relacional. Aos egressos da Escola Militar, grupo que interessa mais de perto aos objetivos desta pesquisa, correspondiam os ex-alunos da Escola Militar da Praia Vermelha. Alguns deles atingiram o auge da carreira militar, outros, pelo envolvimento em revoltas, saíram da formação militar e retornaram a Sergipe, dedicandose à carreira do magistério. Estes últimos foram responsáveis por uma renovação cultural na área educacional. Seus principais representantes foram exatamente Abdias Bezerra e José de Alencar Cardoso, os dois diretores da instrução pública durante o governo Graccho Cardoso.

Ao dissertar sobre esses egressos, Calazans relata as dificuldades das camadas média e baixa da população sergipana de encontrar trabalho e dar continuidade aos estudos, em decorrência da falta de instituições de ensino superior em Sergipe. Isto, segundo o autor, levava estas camadas da população sergipana a trilhar: "[...] a carreira das armas. Assentando praça no exército ou na marinha, o sergipano encontrava os meios necessários à sua própria manutenção e tinha diante de si um futuro assegurado, se vencesse o 'cano de fogo' e não fosse envolvido nas frequientes rebeldias da caserna dos primeiros anos da República [...]” (SILVA, 1965, p. 54).

A falta de outra instituição de ensino superior, além do Seminário Sagrado Coração de Jesus, levava as famílias das camadas médias da população sergipana a encaminhar seus filhos a outros estados com o objetivo de dar sequência aos estudos, por exemplo, nas Faculdades de Direito do Recife e de São Paulo, nas Faculdades de Medicina da Bahia e do Rio de Janeiro ou nas Escolas Militares do Exército e da Marinha (NUNES, 1984).

Oliva de Souza (1985) permite-nos distinguir as parcelas das camadas médias que enviavam seus filhos para complementação de seus estudos e os locais onde o faziam. A autora nos mostra que os membros dos "grupos destituídos" que, em decorrência da crise da produção canavieira do início do século XX, perderam espaço na sociedade da época, enviavam seus integrantes para estudar nas Faculdades de Direito do Recife (principalmente) e de São Paulo e nas Faculdades de Medicina da Bahia e do Rio de Janeiro. Outros, das camadas médias, membros do funcionalismo, dos pequenos 
comerciantes e dos empregados do comércio, por não possuírem recursos financeiros suficientes para manter os filhos nas Faculdades de Direito e Medicina, encaminhavam-nos às Escolas Militares do Exército ou da Marinha, que possuíam um ensino "gratuito e de qualidade".

Alguns sergipanos, alunos das escolas militares não progrediram na carreira. Houve quem se envolvesse em quarteladas no início da República e fosse desligado das escolas. Obrigados a retornar a Sergipe por esse ou por outros motivos, tiveram papel relevante na terra natal. Alguns integraram a administração pública em postos de direção. Entre eles, houve aqueles que se dedicaram ao magistério, tornando-se importantes professores nas primeiras décadas do século XX. Abdias Bezerra, Arthur Fortes e José de Alencar Cardoso foram exemplos desses ex-alunos da Escola Militar da Praia Vermelha.

Em 1889, a Academia Real Militar foi dividida, originando a Escola Superior de Guerra e a Escola da Praia Vermelha. Até 1897 o ensino nesta última estava dividido em três anos de curso preparatório e três anos de curso de armas. Depois desse período seus melhores alunos eram enviados à Escola Superior de Guerra com o objetivo de cursarem mais dois anos de estudos, completando a formação (CARVALHO, 1978). Monarcha (1989, p. 42) lembra-nos que, "no final do século XIX o motor modernizador foi a ciência. No Brasil essa ciência brotaria das academias militares e nas faculdades de direito e medicina. A elite dissidente se comporá em grande parte de militares".

Benjamim Constant foi professor da Escola da Praia Vermelha, reformando seu ensino e consolidando a influência positivista na mesma, tornando-a, antes "um centro de estudos de matemática, filosofia e letras do que de disciplinas militares", segundo Carvalho (1978, p. 195). Assim, formava-se um militar com características mais de bacharel que de um técnico militar. Essa formação de certo contribuiu para as boas condições para o exercício do magistério de Abdias Bezerra e Alencar Cardoso, expulsos da instituição por terem se envolvido na Revolta da Vacina, em 1904, na cidade do Rio de Janeiro.

Os envolvidos com o levante foram, posteriormente, anistiados, momento a partir do qual, José de Alencar Cardoso e Abdias Bezerra retornaram a Sergipe ${ }^{4}$. Nesse período o estado encontrava-se com consideráveis problemas econômicos, devido à crise açucareira. Esta se deveu, em plano internacional, à concorrência com o açúcar de beterraba; no plano nacional, em decorrência do processo de modernização da indústria e agricultura açucareiras; em nível local, por sua vez, pela dificuldade de escoamento da produção. Alencar Cardoso e Abdias Bezerra encontraram também um incipiente processo de urbanização e industrialização nas cidades de Estância e de Aracaju, sedes das duas maiores fábricas de tecidos de Sergipe, fruto do surto algodoeiro dos primeiros anos do século XX.

Em relação à política, o estado estava sob o governo da oligarquia do Monsenhor Olympio Campos, que conseguindo restringir a atuação da oposição, forçava uma parte do grupo representado pelos "doutores" a emigrar para o Rio de Janeiro (OLIVA DE SOUZA, 1985, p. 48). A proximidade do processo eleitoral de 1905 estimulou uma oposição sistemática ao olimpismo, que resultou na eleição de dois deputados federais: Fausto Cardoso e o general Oliveira Valladão. Resultou também na eleição de um senador, Coelho e Campos. Como fruto do processo eleitoral, podemos registrar a Revolta de Fausto Cardoso, em 1906, que objetivou derrubar a oligarquia olimpista, através da deposição do Presidente Guilherme Campos, irmão de Olympio Campos. Para José Calazans Silva, este movimento político foi:

[...] principalmente, um choque de mentalidade, o livre pensamento contra o dogma, liberdade versus caciquismo. O pequeno Sergipe, que aparecera 
na segunda metade do século XIX, revolucionando o pensamento nacional com Tobias e Sílvio, tentava fazer a passos largos sua evolução política e social. Em última análise, o movimento de 1906 foi consequiência lógica dos princípios pregados pela escola teuto-sergipana. [...] Preparavam-na aos poucos, bacharéis imbuídos dos ideais da época tobiária - moços que ouviram a palavra do Mestre na Cátedra gloriosa do Recife - jovens idealistas, expulsos da Escola Militar, em conseqüência dos diversos movimentos revolucionários do começo do século, que retornavam á terra natal, com a carreira cortada, mas repletos de são idealismo [...]. (SILVA, 1965, p. 19-23).

Nesse contexto político-econômico Abdias Bezerra e José de Alencar Cardoso integraram-se individualmente ao grupo dos "Bachareis do Recife", participando da Revolta de Fausto Cardoso. Poucos anos depois, começaram a participar mais diretamente na vida política sergipana, por meio do exercício de cargos da administração pública. Abdias Bezerra iniciou-se como Professor do Atheneu Sergipense, no governo de José Rodrigues da Costa Dória (1908-1911) e José de Alencar Cardoso como Escriturário da Saúde dos Portos, no governo do General Siqueira de Menezes (1912-1914).

Na década de 1920, o Presidente Graccho Cardoso armou-se, no seu governo, da assessoria de intelectuais provenientes das camadas médias da população, tendo espaço os egressos da Escola Militar como Abdias Bezerra, Diretor da Instrução Pública e Arthur Fortes, seu líder na Assembleia Legislativa. Este assumiu também a direção da Escola Normal após a renúncia de Abdias Bezerra, que alegara excesso de trabalho devido ao acúmulo dos cargos de Diretor da Instrução Pública e do instituto de formação de normalistas (SERGIPE. Mensagem..., 1925, p. 21). Além destes dois, participou também do governo Graccho, o professor José de Alencar Cardoso como Diretor da Instrução Pública. Ao cerca-se desses profissionais, garantia Graccho Cardoso um espaço maior de manobra política, permitindo a efetivação do projeto político de modernização do estado de Sergipe, que entre outras ações buscou melhorar as obras de infraestrutura em diversos municípios.

Todos esses aspectos podem ser considerados como redes de sociabilidades entre Graccho Cardoso, Abdias Bezerra e José de Alencar Cardoso. Essas redes compreendem, conforme Sirinelli (2003), a organização dos intelectuais em torno de uma sensibilidade que pode ser ideológica e/ou cultural bem como de outras afinidades, que também relevantes, influenciam nas concepções e ações dos envolvidos nas redes. Os laços desses intelectuais sergipanos advinham desde a formação destes na Escola Militar e chegaram a se concretizar também por meio de uma série de documentos voltados para a organização da instrução pública no estado de Sergipe no início do século XX. Relações de amizade ou de rivalidade, por exemplo, também compõem as redes de sociabilidades. A análise dessas relações de cunho emotivo, contudo, não pode ser feita de forma a colocá-las como determinantes nas ações dos sujeitos. Elas precisam ser inseridas na análise das relações de cunho político, social e cultural.

Outro elemento que compõe as redes são as solidariedades de idade e as implicações de herança a elas inerentes. Sirinelli (2003) destaca os processos de transmissão da cultura vividos pelos intelectuais, seja no âmbito das referências recebidas seja na esfera do movimento de transmissão das suas percepções. Redes de solidariedade de idade podem ser clara e diretamente relacionadas à noção de geração de Gomes (1999), como já explicitada. A autora salienta a relevância de o pesquisador investigar os "lugares" de sociabilidade de uma geração, como escolas, revistas, jornais, reuniões, por exemplo. Lugares de produção e circulação de ideias. Esses ambientes podem ainda ser marcados 
pela afetividade a partir da qual podem resultar relações de amizade ou desavença, proximidade ou até mesmo hostilidade.

Dessa maneira, a noção de geração de Gomes (1999) e à de redes de sociabilidade de Sirinelli (2003) contribuíram para a análise presente neste trabalho acerca das ações de Graccho Cardoso, Abdias Bezerra e José de Alencar Cardoso, vinculados ao cenário educacional sergipano do início do século XX. O conhecimento de características mais específicas sobre esses dois últimos personagens: Abdias Bezerra (diretor entre 1923-1925) e José de Alencar Cardoso (diretor em 1922 e 1926), possibilitaram melhor compreensão das ações destes, empreendidas na Diretoria da Instrução Pública na administração Graccho Cardoso 5 .

\section{OS DIRETORES DA INSTRUÇÃO NO QUADRIÊNIO GRACCHO}

Podemos afirmar que o êxito da política oficial do governo Graccho referente à instrução pública, organizada em grande medida pela Reforma de 1924, foi parte, especialmente, da dedicação do professor Abdias Bezerra, Diretor da Instrução no período reformador. O próprio "Sergipe Jornal”, adversário do governo Graccho a partir de meados de 1924, ao se referir a Abdias Bezerra, afirmava, em 1925, que

[...] principalmente depois de visita a São Paulo, quer celebrar e modernizador a educação em Sergipe. Com apoio das autoridades, colegas e amigos Abdias Bezerra é a inspiração maior, em 1925, das reuniões preparatórias do pioneiro Congresso dos Professores Primários de Sergipe, marcado para 01/01/1926, evento que tem o apoio de Etelvina Amália de Siqueira, Quintina Diniz, Leonor Teles de Menezes, Sirena do Prado e Silva, Maria Amélia Fontes, Helvécio de Andrade, Edgar Coelho, Artur Fortes, José de Alencar Cardoso e Manoel José dos Santos Melo. (Sergipe Jornal. Aracaju, 04/09/1925).

Nascido na então Vila de Siriri, em 07 de setembro de 1880, Abdias Bezerra teve uma vida de perdas. Segundo o Desembargador Hunald Cardoso (1947, p. 91), ele "perdeu o pai aos nove anos de idade e a mãe aos dezesseis. Aos doze, era quase analfabeto". A partir da morte do pai e para ajudar sua mãe, foi ser caixeiro em Japaratuba, Rosário e em Nossa Senhora das Dores. Aos dezessete anos transferiu-se para Aracaju a fim de estudar. Com a ajuda de seu tio Guilhermino Amâncio Bezerra, doutorando em Medicina pela Faculdade da Bahia no período, iniciou seus estudos no Atheneu. Nesta unidade de ensino, Abdias Bezerra fez exames, reuniu certificados e a partir daí se dirigiu para o Rio de Janeiro em 1900 a fim de seguir carreira militar. Naquele momento, esta era a opção mais corrente aos desprovidos da fortuna, refúgio para os que não possuíam condições financeiras de formação no ensino superior. Após quatro anos, o envolvimento no levante contra a vacina obrigatória fez com que Abdias fosse expulso do Exército, retornando ao Estado de Sergipe.

Na Presidência de Graccho Cardoso (1922-26) foi Diretor do Atheneu Sergipense, da Escola de Comércio Conselheiro Orlando, da Escola Normal e Diretor Geral da Instrução Pública. Nesse momento foi designado para ir a São Paulo estudar os processos de ensino vigentes naquele estado com o intuito de introduzi-los na instrução pública sergipana, segundo Hunald Cardoso, recusando a gratificação que lhe foi oferecida a título de recompensa pelos serviços executados (1947, p. 94). Suas observações permearam o 
Regulamento da Instrução de março de 1924 e o Programa para o curso primário elementar e superior decretado em dezembro de $1924^{6}$.

Abdias Bezerra renunciou no penúltimo ano do governo Graccho ao cargo de Diretor Geral da Instrução. Com a sua saída reassumiu em dezembro de 1925 a direção dos serviços de instrução no estado o professor José de Alencar Cardoso ${ }^{7}$. O motivo da renúncia não foi explicado em mensagem de Graccho Cardoso à Assembleia Legislativa do ano de 1926 (SERGIPE. Mensagem..., 1926, p.80). Nesta informava apenas sobre a mudança na direção do cargo. Da mesma forma, os documentos recebidos e expedidos pela Instrução Pública, analisados nesta pesquisa, não indicavam motivos para a saída do professor Abdias da Diretoria Geral da Instrução. Devido a não identificação de discordâncias político-administrativas com o Governo Graccho Cardoso, pressupomos que o professor Abdias Bezerra, que já renunciara à direção da Escola Normal alegando excesso de trabalho, também tenha utilizado o mesmo argumento em relação ao seu desligamento da Diretoria da Instrução, optando por voltar a exercer somente o seu cargo de docente do Atheneu Sergipense.

O novo diretor da instrução, José de Alencar Cardoso, nasceu em 18 de abril de 1878, no município de Estância. Estudou em Aracaju onde fez os preparatórios no Colégio Atheneu Sergipense. Ao retornar a Sergipe, após envolvimento na Revolta da Vacina, ingressou na carreira do magistério, fundando o Colégio Tobias Barreto na cidade de Estância. Naquele momento, "a ajuda do seu pai, Severino Cardoso e principalmente do seu tio, Brício Cardoso teve papel fundamental na elaboração e implantação de um projeto político mais consciente e sistemático, responsável pela aglutinação dos egressos de escola militar: o Colégio Tobias Barreto" (MANGUEIRA, 2003, p. 28).

Brício Maurício de Azevedo Cardoso, tio de José de Alencar Cardoso e pai do Presidente Graccho Cardoso (1922-26), nasceu em 1844 na cidade de Estância. Foi deputado provincial e professor de Português, Latim e História da Civilização de alguns estabelecimentos de ensino e principalmente do Atheneu Sergipense. Segundo Mangueira (2003, p.28), foi Brício Cardoso quem sugeriu ao sobrinho a criação de um colégio, "que atendesse aos interesses das camadas médias emergentes". Brício Cardoso anteriormente tinha sugerido a seu sobrinho a continuidade de seus estudos na Escola Militar da Praia Vermelha, como fizera também com seu filho, Maurício Graccho Cardoso. Naquela escola José de Alencar Cardoso recebeu uma formação que o habilitava para o magistério militar, dentro do pensamento positivista, como afirma Coelho com base no depoimento do general Setembrino de Carvalho: "[...] À conclusão dos cursos científicos na Escola Militar da Praia Vermelha, procuravam iniciar-se no magistério militar, não só pelas vantagens pecuniárias como porque era o meio de fugir à caserna" (CARVALHO apud COELHO, 1976, p. 62).

Foi com essa formação para o magistério, proveniente da família e da Escola Militar, que José de Alencar Cardoso, aos 31 anos de idade, criou em 09 de maio de 1909, na cidade de Estância, o Colégio Tobias Barreto. Junto ao professor Alencar Cardoso estiveram Abdias Bezerra e Arthur Fortes executando um programa autoritário, mas com características modernizadoras da educação sergipana. Ao lado de uma organização marcada pela rigidez disciplinar, estava o método de ensino intuitivo ${ }^{8}$ e práticas de educação física. O Colégio consistia em um estabelecimento civil. Entretanto, mantinha o espírito de uma escola militar.

Já pela organização inicial do Colégio era possível perceber aspectos da concepção de educação escolar de Alencar Cardoso. A militarização era a característica fundamental da instituição, explicitada na forte disciplina e na organização hierárquica no "Tobias Barreto". O Colégio, 
[...] Também se distinguia por uma opção pedagógica moderna com um currículo diferente, objetivando dar maior dinamicidade ao ensino, através da implantação das aulas de educação física, bem como pela ênfase nos aspectos práticos das disciplinas. Esta pedagogia moderna estava assentada numa base moral cristã, com um rígido controle disciplinar sobre o alunado, [...] (MANGUEIRA, 2003, p. 41).

No início do ano letivo de 1912, o professor Alencar Cardoso afastou-se provisoriamente da direção do Colégio, assumindo interinamente em seu lugar o Dr. Jessé Fontes. Alencar Cardoso aceitava o cargo de Escriturário da Saúde dos Portos no Governo do General Siqueira de Menezes, o que o levaria a se mudar para Aracaju. O afastamento provisório pode ser visto como um meio de conciliar os novos interesses com a manutenção do Colégio. De acordo com Mangueira (2003, p. 40), Alencar Cardoso necessitava ao mesmo tempo adaptar-se à nova cidade e às relações políticas inerentes ao exercício do cargo bem como viabilizar uma posterior transferência do estabelecimento para a Capital, a qual ocorrera em 1913.

Em Aracaju a instituição cresceu. A matrícula de 70 alunos no ano de $1911 \mathrm{em}$ Estância, para uma matrícula de 269 alunos em 1919, demonstra o fato que colocava o Colégio como o maior entre os estabelecimentos particulares de ensino no estado. Este crescimento do "Tobias Barreto" durante os três governos militares de 1912 a 1922 General Siqueira de Menezes, General Valladão, Coronel Pereira Lobo - também sinalizava para a tranquila relação entre o seu proprietário, Alencar Cardoso, e os presidentes do estado. Nesse período o professor Alencar Cardoso projetou-se e legitimouse como homem público, possuidor de competência técnica e política para ocupar cargos políticos como o de Inspetor Geral da instrução pública primária, na década de 1910, de Tesoureiro da Delegacia Fiscal (1923-25) e de Diretor da Instrução Pública no Governo do Coronel Pereira Lobo (1918-22) e, posteriormente, na administração Graccho Cardoso (1922; 1926). Devido a essas constantes nomeações do seu fundador para cargos públicos, o Colégio Tobias Barreto passou por diversos diretores, como Brício Cardoso, Carlos Augusto Cardoso, Alice Ferreira Cardoso, Abdias Bezerra e Arthur Fortes (MANGUEIRA, 2003, p. 50). Na ausência do proprietário da instituição, seus familiares assumiam a direção dos trabalhos. Além desses, a direção do Colégio foi confiada aos excompanheiros de formação militar: Abdias Bezerra e Arthur Fortes. A partir disso, podemos julgar pela existência de similitudes de percepções, cumplicidade de orientações acerca da educação escolar entre os membros do grupo de egressos da Escola Militar.

Desde a implantação do Colégio estava presente a educação física, disciplina que se consolidou como um dos elementos essenciais na concepção de formação do professor Alencar Cardoso, por interiorizar no aluno a disciplina e a hierarquia e demonstrar para a sociedade a sua força produtiva. Para a viabilização do projeto, Alencar Cardoso buscou mesclar a aplicação do método intuitivo, naquilo que ele representava de experimentação para o aluno e a implantação das aulas de educação física. Para os alunos do curso primário do Colégio Tobias Barreto, o seu construtor pensou a educação física de maneira geral, como uma

[...] intervenção pedagógica e higiênica sobre os seus corpos, no intuito de preservar-lhes a saúde. Esta intervenção previa a utilização de fardamentos adequados, com uso de calçados, cuidados com a postura dos alunos quando em pé ou sentados, com a maneira com que os alunos empunhavam o lápis, cuidados com o asseio pessoal, entre outros. Este 
tipo de educação era praticado em todas as aulas do Curso Primário, sob a forma de exercícios ginásticos e jogos de movimentos (MANGUEIRA, 2003, p. 63).

Nas palavras de Figueiredo, José de Alencar Cardoso, querido e respeitado por todas as classes sociais, um dos fundadores, em 19/03/1918, do Centro Socialista Sergipano exerceu, de membro do Conselho de Ensino a Inspetor Geral da Instrução Pública, outros e importantes cargos, o que fez com equilíbrio e dignidade (FIGUEIREDO, 1989, p.13). Após essas experiências, assumiu mais uma vez na década de 1920, a Diretoria Geral da Instrução. Alencar Cardoso deu, portanto, continuidade à execução da Reforma de 1924 no último ano do governo Graccho Cardoso.

\section{A REFORMA DA INSTRUÇÃO DE 1924}

Reformar a instrução pública sergipana era intento do Presidente Graccho Cardoso desde a sua plataforma presidencial. O início do processo deu-se, sobretudo, em 1923 por meio da aprovação da Lei n. $852^{9}$ pela Assembleia Legislativa do Estado. Este diploma legal autorizava o Poder Executivo a reformar o ensino e concomitantemente estabelecia as bases sobre as quais deveria orientar-se a reforma.

No período de discussão sobre a reforma, Abdias Bezerra foi designado para ir a São Paulo conhecer de perto a organização do ensino paulista. A identificação da busca pelo exemplo paulista de organização do ensino não proporciona condições suficientes que nos permita compreender o espírito da reforma de 1924. Ao buscarmos entender quem eram os reformadores, evidenciamos que o espírito da reforma do ensino primário do governo Graccho começou a ser gerado no momento em que o governo decidiu cercar-se de jovens intelectuais de classe média para a condução de assuntos governamentais. Ao tempo em que confiou os mais altos postos da direção dos serviços de instrução pública a membros do grupo de egressos das Escolas Militares, Graccho Cardoso, Advogado, mas também um egresso, autorizava seus antigos companheiros de formação militar, a levar para a instrução pública sergipana, aspectos da formação destes e da orientação pedagógica que já haviam experimentado nos seus trabalhos anteriores no magistério, dos quais podemos destacar a experiência no Colégio Tobias Barreto, onde José de Alencar Cardoso e Abdias Bezerra, além da docência, exerceram o cargo de direção.

A reforma de 1924, em Sergipe, integrou um movimento reformador da instrução brasileira nos anos de 1920, a exemplo do que foi vivenciado em outros estados como São Paulo em 1920, Ceará em 1922, Bahia em 1924, Pernambuco em 1928, Rio Grande do Norte em 1924, Minas Gerais em 1927 e Distrito Federal em 1927. As reformas apresentavam-se como momentos de transformações para a melhoria da instrução pública, é necessário analisá-las em sua historicidade, percebendo mudanças e permanências e o alcance destas a fim de melhor compreender a realidade vivida ou pretendida no período.

Em São Paulo, o governo Washington Luís modificou a reforma de autoria de Sampaio Dória (1920) independente do posicionamento de seu autor. O Diretor da Instrução Pública de Sergipe, quando chegou a São Paulo em 1923, não observou a reforma paulista em sua origem. Ao verificar a organização do ensino daquele estado teve contato com a reforma "reformada", ou seja, alterada pelo governo sem a participação de Sampaio Dória. Os resultados da viagem de Abdias Bezerra foram contemplados no Regulamento da instrução de março de 1924 e no Programa para o curso primário, elementar e superior decretado em dezembro do mesmo ano, e demais textos legais e recomendações durante o Governo. 
Através da análise do Regulamento da instrução de 1924 podemos averiguar a projetada organização do ensino público sergipano, segundo os reformadores, e em comparação com regulamentos anteriores compreender as transformações e as continuidades das regulamentações. O Regulamento de 1924 trazia determinações para todos os níveis de ensino (primário, profissional e secundário); inaugurava a regulamentação de jardins de infância e escolas maternais; detalhava as atribuições das autoridades envolvidas com a instrução; discorria sobre os subsídios financeiros para o ensino através de fundo escolar e caixas escolares; dava tratamento aos materiais escolares; prescrevia normas para o uso do método de ensino intuitivo; ocupava-se com o ensino religioso; entre outros aspectos. O documento estava organizado ao longo de 115 páginas onde se ordenavam 57 capítulos e 472 artigos. Destes, 320 artigos distribuídos por 37 capítulos em 78 páginas dedicavam-se à reforma do ensino primário (SERGIPE. Regulamento..., 1924).

O contato do professor Abdias Bezerra com a reforma de Sampaio Dória possibilitou mudanças na organização do ensino primário em Sergipe. No entanto, estas dividiram espaço tanto com a permanência de orientações provenientes de reformas anteriores ao governo Graccho, quanto com as representações do presidente do estado e do diretor da instrução pública sergipana sobre educação e modernidade. As representações dos sujeitos são consequências de processos de apropriação e, segundo Chartier (1990), são tão importantes para a compreensão da história quanto as lutas políticas ou as crises econômicas, já que englobam os conhecimentos dos indivíduos e suas práticas. Diante disso, afirmamos que a experiência sergipana não pode ser tomada apenas como um exemplo do que foi posto em prática em São Paulo. Ao investigar a realidade sergipana, verificamos a existência de especificidades à espera de análise específica para uma verdadeira compreensão dos eventos.

O estudo da organização do ensino paulista pelo professor sergipano Abdias Bezerra gerou como principal mudança para a instrução em Sergipe a divisão do ensino primário em níveis e a redução da gratuidade e obrigatoriedade da escolarização ao primeiro desses níveis.

O ensino primário sergipano passava a ser organizado em seis anos divididos em ensino primário elementar e ensino primário superior. Obrigatoriedade e gratuidade eram reduzidas de quatro para os três anos correspondentes ao curso elementar. Todavia, essa influência não resultou na cópia fiel do modelo. Em São Paulo, o ensino primário obrigatório de quatro anos havia sido reduzido para dois anos de escolarização. A carga horária diária de aulas, igualmente reduzida, também apresentava diferenças em relação ao modelo. Em Sergipe esse período de trabalhos escolares foi reduzido de cinco para quatro horas diárias, enquanto que em São Paulo, a redução havia ocorrido para apenas duas horas e meia por dia.

A diferença pode ser explicada ao considerarmos as representações do governante de Sergipe. Este, em sua plataforma de governo, apresentava características de um ensino escolar que se aproximava da escola nova e, ao assumir o governo, buscou orientação em São Paulo para tratar os assuntos relativos ao ensino primário. No entanto, Sampaio Dória, responsável pela reforma paulista, não se declarava escolanovista no período e seu projeto apresentava orientações de pensamentos diversos. Uma maior aproximação de Sampaio Dória com a escola nova ocorreu após a sua saída da Diretoria da Instrução de São Paulo. Os resultados da reforma paulista mostraram que, por meio dela, o ensino primário tornouse essencialmente promotor de alfabetização.

O ensino primário para o governo Graccho Cardoso, no entanto, era compreendido como base para o progresso, contribuinte para a elevação do grau de civilização e 
modernidade da sociedade. Assim, a escola primária, segundo o presidente de Sergipe, não poderia ser reduzida à alfabetização. Ela deveria preparar a criança para a vida e para o trabalho. Ao partir dessa premissa, foi que, por exemplo, apresentou em sua plataforma de governo, largamente publicada na imprensa da época e depois determinou via regulamento da instrução pública, o ensino diferenciado para as escolas, a depender da sua localização (ensino regional). Determinava-se um programa de ensino uniforme para todas as escolas, oferecendo, contudo, possibilidades de acréscimo de informações próprias da realidade local dos alunos (SERGIPE. Regulamento..., 1924).

Outra mudança experimentada na instrução, em decorrência da Reforma de 1924, sob a influência paulista, foi a alteração no serviço de inspeção escolar devido ao estabelecimento das Delegacias de Ensino. Isto ocorria, no entanto, sem alterações nos objetivos e atribuições dos responsáveis pela fiscalização das escolas. Estes, adequando-se à nova legislação da instrução, tinham alteradas apenas a denominação dos seus cargos: inspetores escolares e delegados do ensino passaram, a partir de 1924, a ser chamados, respectivamente, de delegados do ensino e encarregados escolares. A normatização relativa às atribuições dos cargos permanecia sem alterações em relação às normas instituídas em Sergipe em reformas anteriores, a exemplo da decretada no governo Pereira Lobo (19181922) em 1921 (SERGIPE. Leis e Decretos..., 1928).

Relações entre a reforma paulista e a regulamentação sergipana de 1924 podiam ser vistas por meio da determinação do funcionamento do serviço de inspeção médicosanitária. Entretanto, tal serviço não chegou a ser posto em prática. Mas, preocupações higienistas nas escolas públicas já eram frequentes nas instituições de ensino de Sergipe desde regulamentações anteriores, a exemplo da reforma de 1911 no governo Rodrigues Dória (1908-1911), na qual já se estabeleciam determinações de caráter higienista, como a exigência da comprovação de vacinação dos alunos no momento das matrículas nas escolas públicas (AZEVEDO, 2009).

Um outro exemplo de ação identificada à orientação paulista foi a criação das Escolas Reunidas. Este tipo de instituição de ensino primário, apesar de já fazer parte do sistema de ensino de São Paulo, destacou-se a partir da reforma de Sampaio Dória (1920) em termos quantitativos. No governo Graccho Cardoso, duas escolas reunidas foram criadas: as Escolas Reunidas Esperidião Monteiro, em Santo Amaro e as Escolas Reunidas Severiano Cardoso, em Boquim. Porém, diferentemente do que ocorreu naquele estado, em Sergipe, tais estabelecimentos de ensino não foram expandidos e um deles (em Boquim), inclusive, chegou a se tornar, no final do governo Graccho, grupo escolar ${ }^{10}$. Do exposto, notamos mais uma aproximação com a experiência paulista, marcada, todavia, por diferenças, explicadas em grande medida pelas representações de Graccho Cardoso e dos diretores da instrução pública do seu governo estadual.

As pesquisas sobre a reforma de 1920 em São Paulo demonstram uma perda do referencial de qualidade próprio dos grupos escolares, instituições consideradas modelo, que sofreram a partir da reforma um movimento de queda nas matrículas e a concorrência com as escolas reunidas (ANTUNHA, 1976; CAVALIERE, 2003). Em Sergipe, evidenciamos um movimento contrário, tanto em termos quantitativos quanto qualitativos. As escolas reunidas não se destacaram e os grupos escolares foram expandidos, inclusive para o interior do estado e mantiveram o referencial de padrão de qualidade, permanecendo como síntese da materialização da educação para a República. Em Sergipe, os grupos escolares tiveram inclusive as suas funções ampliadas. Extinto o Grupo Escolar Modelo, anexo à Escola Normal Rui Barbosa, os demais grupos do estado, passavam a ser também campo de prática docente tanto para alunas da Escola Normal quanto para professoras leigas com atuação nas escolas isoladas. A expansão dos grupos durante a administração 
Graccho Cardoso pode ser, em virtude disso, considerada um dos elementos da reforma de 1924. O êxito desta reforma, na opinião do administrador, aparecia associado à sua execução nos grupos escolares. A avaliação do sucesso baseava-se também na melhoria dos trabalhos escolares com base no método de ensino intuitivo e do sistema de inspeção escolar.

Outra diferença entre as regulamentações paulista e sergipana que merece destaque e a partir da qual podemos identificar representações de Graccho, Abdias e Alencar Cardoso diz respeito à progressão no ensino. Com os grupos escolares, surgiu a necessidade de elaboração de mecanismos de ordenamento dos alunos em classes e séries. A forma encontrada para essa organização foi a instituição de exames. Alvos de regulamentação, os exames, de modo geral, deveriam ser presididos por comissão examinadora, versar sobre as matérias do programa e constar de provas escrita e oral. Essas características dos exames foram conservadas em Sergipe após a reforma de 1924, mantendo-se, inclusive, o ritual público para os exames finais. A reforma não instituiu como em São Paulo, a progressão automática entre os níveis e a proibição da repetência (ANTUNHA, 1976). Ações como estas evidenciavam a presença de concepções dos reformadores da instrução sergipana acerca da educação escolar. Tanto o professor Abdias Bezerra (1923-25) quanto o professor José de Alencar Cardoso $(1922 ; 1926)^{11}$, diretores da instrução pública durante a administração Graccho, eram detentores de experiências na educação escolar, tanto na docência quanto na direção de instituições de ensino, entre as quais se destaca o Colégio Tobias Barreto. Neste estabelecimento de ensino privado, os professores puseram em prática um projeto educacional marcado por uma modernidade pedagógica, consubstanciada em uma rigorosa disciplina escolar, no trabalho com método de ensino intuitivo e na prática de educação física (MANGUEIRA, 2003). A permanência da rigidez no processo de avaliação através dos exames escolares após a reforma de 1924 pode ser associada às concepções educacionais dos diretores da instrução pública marcadas pela forte disciplina.

Os diretores da instrução, Abdias Bezerra e José de Alencar Cardoso, jovens intelectuais, com formação militar, eram adeptos de uma modernidade pedagógica, marcada por uma preocupação higiênica e civilizatória, condizente com as representações de modernidade e educação do presidente Graccho Cardoso. Este, como aqueles, era também egresso da Escola Militar da Praia Vermelha do Rio de Janeiro. O convite do governo estadual aos referidos professores para o gerenciamento dos assuntos de instrução pública mostra-se, dessa maneira, significativo. Dotados de uma formação científica, adquirida na época apenas nas Faculdades de Direito e Medicina e nas Escolas Militares, tais jovens intelectuais sergipanos representavam, no governo Graccho, apoio para a efetivação de um projeto político modernizador do estado e de seus órgãos públicos. Isto ocorria tanto via Poder Executivo, onde tais professores atuaram, quanto por meio do Poder Legislativo, de onde atuou Arthur Fortes, também um egresso e líder do governo na Assembleia Legislativa.

As experiências educacionais de ambos os professores no Colégio Tobias Barreto demonstravam profissionais da educação preocupados com uma organização escolar revestida em moldes considerados modernos. Isso se verifica, através, por exemplo, dos cuidados com a disciplina escolar, da prática do método de ensino intuitivo e da instituição de aulas de educação física, ações que nos levam a vislumbrar uma preocupação ao mesmo tempo pedagógica e higiênica para com a sociedade por meio da educação escolar. $\mathrm{O}$ governo Graccho Cardoso marcado, entre outros aspectos, pela presença na direção de serviços públicos de jovens intelectuais provenientes de classe média, sem raízes nas tradições oligárquicas que marcaram a história política brasileira da passagem do Império 
para a República, dava indícios da sua busca por melhorias na educação escolar pública pela difusão de um concreto processo de modernização pedagógica. As experiências desses professores mostravam-se condizentes com o pensamento de Graccho Cardoso acerca da educação escolar. Compreendemos, a partir disso, o porquê da nomeação desses profissionais e os reais objetivos destes para com a instrução pública sergipana.

\section{FINALIZANDO AS REFLEXÕES}

O contato do professor Abdias Bezerra com a reforma de Sampaio Dória possibilitou mudanças na organização do ensino primário em Sergipe. No entanto, estas dividiram espaço tanto com a permanência de orientações provenientes de reformas anteriores ao governo Graccho, quanto com as representações do presidente do estado e dos diretores da instrução pública sergipana sobre educação e modernidade.

O estudo da organização do ensino paulista pelo professor Abdias Bezerra gerou como principal mudança para a instrução em Sergipe a divisão do ensino primário em níveis e a redução da gratuidade e obrigatoriedade da escolarização ao primeiro desses níveis. Todavia, essa influência não resultou na cópia fiel do modelo. Em São Paulo, o ensino primário obrigatório de quatro anos havia sido reduzido para dois anos de escolarização. Em Sergipe a redução do período de ensino obrigatório se deu de quatro para três anos. A carga horária diária de aulas, igualmente reduzida, também apresentava diferenças em relação ao modelo. Em Sergipe o período de trabalhos escolares foi reduzido de cinco para quatro horas diárias, enquanto que em São Paulo, a diminuição resultou em uma carga horária diária de apenas duas horas e meia.

A diferença pode ser explicada ao considerarmos as representações do governante de Sergipe. Este, em sua plataforma de governo, defendia um ensino escolar que apontava para características da escola nova. Ao assumir o governo, buscou orientação em São Paulo para tratar do ensino primário. No entanto, Sampaio Dória, responsável pela reforma paulista, não se declarava adepto do escolanovismo e seu projeto reformador marcava-se por diferentes orientações de pensamento. Aproximação de Dória a princípios da Escola Nova ocorreu somente após a sua saída da Diretoria da Instrução de São Paulo. Neste estado, como fruto da reforma, o ensino primário tornou-se basicamente promotor de alfabetização, o que não verificamos em Sergipe. Para o governo Graccho Cardoso, o ensino primário era considerado base para o progresso e elevação do grau de civilização e modernidade da sociedade. Dessa forma, a escola primária, segundo o presidente, não poderia ser reduzida à alfabetização, posto que a sua função deveria ser preparar a criança para a vida e para o trabalho. Essa preocupação estava presente em sua plataforma de governo e durante a sua administração estadual foi materializada no regulamento da instrução pública de 1924. Neste foi determinado o ensino diferenciado para as escolas (ensino regional) a partir da sua localização e das suas particularidades. As escolas deveriam respeitar a uniformidade do programa de ensino. Mas, poderiam adotar modificações permitindo o acréscimo de informações próprias da realidade local das escolas e de seu público.

Outras mudanças experimentadas na instrução em decorrência da Reforma de 1924 sob a influência paulista foram: a) a alteração nos trabalhos de inspeção escolar devido ao estabelecimento das Delegacias de Ensino, sem, contudo, modificar as atribuições dos antigos responsáveis pelo serviço de inspeção escolar em Sergipe; b) a determinação do serviço de inspeção médio-sanitária, que não chegou a entrar em funcionamento em Sergipe, o que não significa ausência de serviços voltados para a higiene escolar, presentes nas regulamentações de ensino de Sergipe de forma sistemática desde 1911; e, c) a criação 
das Escolas Reunidas, porém, sem muito empenho em Sergipe, onde foi expandido mesmo um outro tipo de instituição: os grupos escolares. As mudanças na instrução sergipana em decorrência da influência paulista ocorreram. Contudo, dividiram espaço com as influências locais, com destaque para os frutos das experiências dos diretores da instrução pública do governo Graccho Cardoso.

Os diretores da instrução, Abdias Bezerra e Alencar Cardoso, eram adeptos de uma modernização pedagógica, marcada por uma preocupação higiênica e civilizatória, em acordo com as representações de modernidade e educação do presidente Graccho. Este, como aqueles, era também um egresso de Escola Militar. O convite do governo estadual aos referidos professores para o gerenciamento dos assuntos de instrução pública mostrase, dessa maneira, muito significativo. Esses jovens sergipanos representavam no governo Graccho um ponto de apoio para a execução do projeto político de modernização de Sergipe, via administração pública. $\mathrm{O}$ apoio ocorria não apenas no âmbito Executivo. A existência de outro egresso, desta vez no Poder Legislativo contribuía para tanto. Arthur Fortes era líder do governo na Assembleia Legislativa Estadual.

Dessa forma é que podemos afirmar que o espírito da reforma de 1924 em Sergipe não se localizava apenas na experiência paulista. Este espírito encontrava suas bases também representações do presidente do Graccho Cardoso sobre educação e modernidade. Tais representações, por sua vez, revelavam um processo de apropriação de ideias de personalidades diversas, a exemplo de Manoel Luís, em Sergipe, e Rui Barbosa, em nível nacional. Do primeiro, podemos citar a determinação de criação de escolas maternais em Sergipe em 1870, sem efetivação na época. Tal resolução era retomada e aparecia na Reforma de 1924. Acerca do pensamento de Rui Barbosa, percebemos a vinculação de Graccho Cardoso a ele no exemplo da defesa do ensino primário graduado, gratuito e obrigatório, instalado em prédios próprios e adequados a princípios higienistas. Tais princípios eram orientadores de práticas preventivas de doenças por meio, inclusive, da aplicação de vacinas e da instituição de um sistema de inspeção higiênica nas escolas. A defesa da organização de um sistema de educação nacional também atestava relações de Graccho Cardoso com ideias de Rui Barbosa. Além dessas premissas de Graccho Cardoso, podemos considerar que o espírito da reforma de 1924 relacionava-se também com a influência das concepções sobre educação de Abdias Bezerra e de José de Alencar Cardoso.

Em relação às permanências na normatização, a regulamentação de 1924 manteve muito do que foi instituído anos antes pelo regulamento de 1921. A grande mudança ocorreu mesmo no que se refere à redução do período de obrigatoriedade do ensino primário. Este, apesar de organizado para seis anos (elementar e superior) teve sua obrigatoriedade reduzida de quatro para os três correspondentes ao ensino primário elementar. Esta característica da reforma da instrução pública do governo Graccho pode ser considerada o seu traço mais marcante, maior diferenciador entre as reformas da instrução pública anteriores a 1924.

No que se refere às diferenças entre as regulamentações paulista e sergipana que merecem destaque, podemos fazer relação: a) ao sistema de progressão no ensino; se em São Paulo proibiu-se a repetência ao estabelecer a progressão automática, em Sergipe os exames avaliativos permaneceram, mantendo-se, inclusive, os rituais públicos de avaliação com a presença de comissões examinadoras; b) às atribuições do Conselho do Ensino, antes, com função consultiva e deliberativa sobre questões diversas do ensino, passava, a partir de 1924, a atuar apenas na análise de obras didáticas que deveriam ser utilizadas nas escolas. Suas responsabilidades decisórias tornaram-se competências do diretor geral da instrução; c) ao ensino religioso, permitido em Sergipe nas escolas públicas. 
Quanto ao ensino religioso, por meio da historiografia sobre a reforma Sampaio Dória consultada para esta pesquisa, não foram identificadas referências acerca desse tipo de ensino. A partir da constatação das relações existentes entre Graccho Cardoso e a Igreja Católica em Sergipe, com o apoio do governo à edificação de igrejas, construção do monumento ao Cristo Redentor em São Cristóvão e da nomeação de padres para cargos públicos, inclusive direção de grupos escolares, podemos supor que, além da influência paulista, das experiências sergipanas postas em regulamentações anteriores ao seu governo e da apropriação de ideias de Rui Barbosa, as concepções de Graccho permitiram que a instrução pública no seu governo também sofresse influência do grupo católico. Líderes católicos, a partir da década de 1920, muito influenciaram a vida cultural de Sergipe. Estes se formaram no Seminário Sagrado Coração de Jesus, primeira instituição de ensino superior no estado. Tal pressuposto baseia-se também nas representações do professor Abdias Bezerra, diretor da instrução pública e gestor da reforma de 1924. Abdias Bezerra, como nos lembra Carvalho Neto, talvez em decorrência de um legado familiar católico, apresentava traços místicos em seu comportamento, herança cristã, ainda que não ortodoxa (CARVALHO NETO, 1947, 33).

Diante do exposto, evidenciamos que a reforma de 1924 em Sergipe pode ser considerada elemento modernizador no governo Graccho Cardoso. A preocupação com o provimento das instituições de ensino em prédios adequados, materializada na expansão dos grupos escolares e na compra de casas para alojar as escolas isoladas, pode mesmo ser considerada parte integrante da reforma. A execução desta significou um processo de institucionalização do curso primário para o interior do estado, marca de modernização para esse nível de ensino. A Reforma da Instrução Pública de 1924 funcionou com um dos elementos contribuintes de um projeto reformador geral do governo que se pretendia agente de modernização.

O cuidado com a escolarização era considerado um dos principais deveres da administração pública tendo em vista a modernização e o sucesso da República e da democracia. A educação era ingrediente do projeto moderno e civilizador das elites intelectuais republicanas. Apesar de existente no Brasil desde o fim do século XIX, ganhava força na década de 1920, a ideia de educação como necessidade e caminho para o ingresso do país na modernidade. A defesa da escola como preparadora para a vida e para o trabalho fazia com que as instituições de ensino fossem consideradas espaços mesmo de reforma social. Era com base nesses princípios que Graccho Cardoso e os diretores da instrução pública de seu governo em Sergipe (1922-26) pensaram e buscaram implementar mudanças na instrução pública da época, assim como, reviram e deram continuidade a ações já em curso na organização do ensino público, desde que conectadas com as mudanças instauradas.

\section{Referências}

ANTUNHA, Heládio César G. A instrução pública no Estado de São Paulo - a reforma de 1920. São Paulo: Faculdade de Educação/Universidade de São Paulo, 1976.

AZEVEDO, Crislane B. Grupos escolares em Sergipe (1911-1930): cultura escolas, civilização e escolarização da infância. Natal: EdUFRN, 2009.

BARBOSA, Rui. Obras completas de Rui Barbosa - Reforma do ensino primário e outras instituições complementares da instrução pública. v. X, tomo I, 1883a.

CARDOSO, Hunald. Discurso proferido pelo Desembargador Hunald Cardoso no Instituto Histórico e Geográfico a 23 de julho de 1945 na sessão solene do mesmo Instituto. In: 
BEZERRA, Felte. Abdias Bezerra: traços psicológicos de um educador sergipano. Aracaju: [s.n.], 1947.

CARDOSO, Maurício Graccho. Oração do paranympho na collação de gráo dos engenheiros agronomos da Escola Superior de Agricultura e Medicina Veterinaria do Rio de Janeiro. Diario Official do Estado de Sergipe. Aracaju, de 5 a 8 de março de 1922.

Plataforma Presidencial lida pelo Exm. Sr. Dr. Mauricio Graccho Cardoso, na Assembléa Legislativa, após o compromisso prestado para exercer o cargo de Presidente do Estado, no quadriennio de 1922 a 1926. Diario Official do Estado de Sergipe. 854, 27 de outubro de 1922.

. Discurso pronunciado pelo exm. Sr. Dr. Mauricio Graccho Cardoso, Presidente do Estado, na inauguração do Grupo Escolar Vigario Barroso, na cidade de São Christovam, em 2-9-1923. Diario Official do Estado de Sergipe. Aracaju, 4 de setembro de 1923, p.2836-2837.

CARVALHO, José Murilo de. As Forças Armadas na Primeira República: o poder desestabilizador. In: FAUSTO, Boris (Org.). História da civilização Brasileira. 2. ed., São Paulo, Rio de Janeiro: DIFEL, 1978.

CARVALHO NETO. Reminiscências. In: BEZERRA, Felte. Abdias Bezerra: traços psicológicos de um educador sergipano. Aracaju: [s.n.], 1947.

CAVALIERE, Ana Maria. Entre o pioneirismo e o impasse: a reforma paulista de 1920. Educação e Pesquisa. São Paulo, v.29, n.1, p.27-44, jan./jun. 2003.

CHARTIER, Roger. A História Cultural: entre práticas e representações. Tradução de Maria Manuela Galhardo. Rio de Janeiro: Bertrand Brasil; Lisboa: Difel, 1990.

COELHO, Edmundo Campos. Em busca de identidade: o Exército e a política na sociedade brasileira. Rio de Janeiro: Forense Universitária, 1976.

CRUZ COSTA, João. Contribuição à história das idéias no Brasil. Rio de Janeiro: Civilização Brasileira, 1967.

FIGUEIREDO, Ariosvaldo. História politica de Sergipe. v. 2, Aracaju: Sociedade Editorial de Sergipe, 1989.

GOMES, Ângela de Castro. História e historiadores: A política cultural do Estado Novo. 2 ed. Rio de Janeiro: Editora da FGV, 1999.

GUARANÁ, Armindo. Diccionário bio-bibliográfico do Estado de Sergipe. Aracaju: Governo do Estado de Sergipe, 1925.

MANGUEIRA, Francisco I. de O. Collegio Tobias Barreto: escola ou quartel? (19091946). 2003, 117 f. São Cristóvão, Dissertação (Mestrado em Educação). Universidade Federal de Sergipe, 2003.

MONARCHA, Carlos. A reinvenção da cidade e da multidão: dimensões da modernidade brasileira: a Escola Nova. São Paulo: Cortez; Autores Associados. 1989

NUNES, Maria Thétis. História da educação em Sergipe. Rio de Janeiro: Paz e Terra; Aracaju: Secretaria de Educação e Cultura do Estado de Sergipe; Universidade Federal de Sergipe, 1984.

OLIVA DE SOUZA, Terezinha. Impasses do federalismo brasileiro: Sergipe e a Revolta de Fausto Cardoso. Rio de Janeiro: Paz e Terra; São Cristóvão: UFS, 1985.

PROFESSOR Alencar Cardoso. Correio de Aracaju. Aracaju, 12/02/1922, n. 3349. 
PROFESSOR Abdias Bezerra. Sergipe Jornal. Aracaju, 06/09/1923, n. 607.

PROFESSOR Alencar Cardoso. Sergipe Jornal. Aracaju, 18/04/1923, n. 497.

PROFESSOR Alencar Cardoso. Sergipe Jornal. Aracaju, 19/04/1923, n. 498.

SERGIPE. Regulamento Geral da Instrucção Publica do Estado de Sergipe, expedido conforme decreto n. 867, de 11 de março de 1924. Aracaju: Typ. do "O Estado de Sergipe", 1924.

SERGIPE. Mensagem apresentada á Assembléa Legislativa, em 7 de Setembro de 1923, ao installar-se a $1^{a}$ Sessão Ordinaria da $15^{a}$ legislatura, pelo Dr. Mauricio Graccho Cardoso, Presidente do Estado. Aracaju: Imprensa Official, 1923.

SERGIPE. Mensagem apresentada á Assembléa Legislativa, em 7 de Setembro de 1925, ao installar-se a $3^{a}$ Sessão Ordinaria da $15^{a}$ legislatura, pelo Dr. Maurício Graccho Cardoso, Presidente do Estado. Aracaju: Imprensa Official, 1925.

SERGIPE. Mensagem apresentada á Assembléa Legislativa, em 7 de Setembro de 1926, ao installar-se a $1^{a}$ Sessão Ordinaria da $16^{a}$ legislatura, pelo Dr. Mauricio Graccho Cardoso, Presidente do Estado. Aracaju: Typ. de Instituto Profissional Coelho e Campos, 1926.

SERGIPE. Colleção de Leis e decretos do Estado de Sergipe de 1923: atos do poder legislativo e atos do poder executivo 1923. Aracaju: Typ. de "O estado de Sergipe", 1929.

SERGIPE. Decreto n. 724 - de 20 de outubro de 1921. Dá novo Regulamento á Instrucção Publica. In: Leis e Decretos do Estado de Sergipe de 1921. Aracaju: Imprensa Official, 1928, p. 48-136.

SERGIPE JORNAL. Aracaju, 18/04/1922, n. 212.

SERGIPE JORNAL. Aracaju, 04/09/1925.

SERGIPE JORNAL. Aracaju, 15/03/1923, n. 471.

SILVA, José Calazans B. da. O desenvolvimento cultural de Sergipe na primeira metade do século XX. Revista do Instituto Histórico e Geográfico de Sergipe. Aracaju, v. XXI, n. 26, p. 46-57, 1965.

SIRINELLI, Jean François. Os intelectuais. In: RÉMOND, René. Por uma história política. Tradução de Dora Rocha. 2 ed. Rio de Janeiro: Editora da FGV, 2003.

VIEIRA, Carlos Eduardo. Intelligentsia e intelectuais: sentidos, conceitos e possibilidades para a história intelectual. Revista Brasileira de História da Educação. Campinas: Autores Associados, n. 16, p. 63-85, Janeiro-abril/2008.

\section{NOTAS}

\footnotetext{
${ }^{1}$ Crislane Barbosa de Azevedo é Licenciada e Bacharel em História pela Universidade Federal de Sergipe, Mestre em Educação e Contemporaneidade pela Universidade do Estado da Bahia e Doutora em Educação pela Universidade Federal do Rio Grande do Norte. É Professora Adjunta do Centro de Educação da Universidade Federal do Rio Grande do Norte. Email: crislaneazevedo@ yahoo.com.br

${ }^{2}$ Para a direção do Departamento Estadual do Algodão foi contratado o professor Thomás R. Day, do Texas. Para a organização e direção inicial do Instituto de Química foi contratado o Dr. Archimedes Pereira Guimarães, professor da Escola Polytechnica da Bahia e com passagem na Escola Superior de Agricultura e Medicina Veterinária, no Rio de Janeiro. A direção do instituto de pesquisas médicas e laboratório de análises clínicas - Instituto Parreiras Horta, foi confiada ao bacteriologista que lhe deu nome, Paulo de
} 
Figueiredo Parreiras Horta, que o dirigiu até dezembro de 1925, quando se retirou do Estado para continuidade de suas pesquisas e outros compromissos profissionais. A coordenação da reforma dos serviços de abastecimento de água, esgotos e drenagem de Aracaju ficou a cargo do engenheiro sanitário, Dr. Saturnino de Brito, do Rio de Janeiro. (SERGIPE. Mensagem..., 1923 e 1925).

3 No Demonstrativo de receitas e despesas do quadriênio 1922-1926 apresentado pelo Presidente à Assembleia Legislativa em setembro de 1926, os itens: Biblioteca Pública; Diretoria de Higiene; Patronato São Maurício; Instituto Coelho e Campos; Instituto de Química; Aquisição de livros e material escolar para alunos pobres; Aquisição e reforma de mobiliário escolar, aparecem separados de Instrução Pública, que compõe um item que sozinho totaliza o valor de 3.132:358\$756. Os demais itens foram postos na Tabela 1 por entender que os mesmos relacionam-se diretamente às preocupações com a educação da população e, portanto, devem ser consideradas despesas com instrução pública.

${ }^{4}$ Arthur Fortes também foi anistiado e retornou a Sergipe. Durante o governo Graccho Cardoso (1922-26) foi o principal representante do Governo na Assembleia Legislativa.

${ }^{5}$ Eram comuns notas e informes sobre os professores Abdias Bezerra e José de Alencar Cardoso na imprensa da época, são exemplos desses registros: Professor Alencar Cardoso. Correio de Aracaju. Aracaju, 12/02/1922, n. 3349; Sergipe Jornal. Aracaju, 18/04/1922, n. 212; Professor Abdias Bezerra. Sergipe Jornal. Aracaju, 06/09/1923, n. 607; Professor Alencar Cardoso. Sergipe Jornal. Aracaju, 18/04/1923, n. 497; Professor Alencar Cardoso. Sergipe Jornal. Aracaju, 19/04/1923, n. 498.

${ }^{6}$ Decreto no 867 de 11 de março de 1924 - Dá novo Regulamento à instrução pública e Decreto n o 892 de 20 de dezembro de 1924 - Aprova programas para os cursos primários, elementar e superior. O Regulamento de 1924 além de constar nos documentos legislativos foi confeccionado em forma de obra independente. O exemplar publicado pela Imprensa Official sugere assim que ao lado do cumprimento das normas o Regulamento deveria ser visto e lido.

${ }^{7}$ Foi diretor da instrução no governo Pereira Lobo (1918-1922). Permaneceu no cargo até março de 1923, já na administração Graccho. Saiu em decorrência da nomeação para o cargo de tesoureiro da "Delegacia Fiscal do Thesouro Nacional” em Sergipe. Ver: Sergipe Jornal. Aracaju, 15/03/1923, n. 471.

${ }^{8} \mathrm{O}$ método de ensino intuitivo começou a ser divulgado no Brasil no final do século XIX e esteve na base das discussões sobre a organização da escola primária. De acordo com tal método, o professor deveria utilizar diversos objetos do cotidiano da criança a fim de possibilitar o exercício dos seus sentidos (ver, pegar, ouvir, cheirar) para, a partir de então, abrir-se caminho para a abstração em um processo no qual a capacidade de raciocinar levasse a criança à verdadeira aprendizagem. Os sentidos poderiam ser mesmo considerados como instrumentos da aprendizagem. Objetivava-se um aprendizado produtivo e não apenas a transmissão de conhecimentos. Explorar os sentidos exigia observação e experimentação. A aprendizagem era buscada de forma prática, concreta, para só a partir de então, buscar-se a abstração, momento em que os alunos teriam a possibilidade de pensar e criar cientificamente e não apenas apropriar-se de conhecimentos prontos. $\mathrm{O}$ método intuitivo contrapunha-se, assim, ao ensino verbalista e memorizador. A aprendizagem ocorreria através das percepções sobre as coisas (objetos) e da experiência, a partir das quais as ideias seriam desenvolvidas. A experiência baseada nos sentidos deveria ser ainda associada à recreação, estratégia para 0 desenvolvimento da criatividade dos alunos com o fim de levá-los à educação intelectual.

${ }^{9}$ Sergipe. Lei n. 852, de 30 de outubro de 1923 - Estabelece bases para a reforma do ensino primário e normal do Estado. In: Colleção de Leis e decretos do Estado de Sergipe de 1923: atos do poder legislativo e atos do poder executivo 1923. Aracaju: Typ. de "O estado de Sergipe”, 1929, p. 28-36.

${ }^{10}$ Decreto n. 968 de 20 de outubro de 1926 - Considera Grupo Escolar as Escolas Reunidas "Severiano Cardoso". Ver: SERGIPE. Colleção..., 1926.

${ }^{11}$ José de Alencar Cardoso foi diretor da instrução durante o governo do coronel Pereira Lobo (1918-1922) e no início da administração Graccho (1922). Mas, deixou o cargo, em março de 1923, quando foi nomeado tesoureiro da "Delegacia Fiscal do Thesouro Nacional” em Sergipe. (Sergipe Jornal. Aracaju, 15/03/1923). Retornou ao cargo em 1926 após renúncia do professor Abdias Bezerra.

Recebido em setembro-13

Aprovado em novembro-13 